\title{
Decline in the prevalence of anaemia among children of pre-school age after implementation of wheat flour fortification with multiple micronutrients in Jordan
}

\author{
Rami Al Rifai, Keiko Nakamura* and Kaoruko Seino \\ Department of International Health and Medicine, Division of Public Health, Graduate School of Medical and Dental \\ Sciences, Tokyo Medical and Dental University, Bunkyo-ku, Tokyo, Japan
}

Submitted 26 March 2015: Final revision received 25 August 2015: Accepted 1 September 2015: First published online 5 October 2015

\begin{abstract}
Objective: To examine changes in the prevalence of anaemia and its correlates among children of pre-school age after implementation of wheat flour fortification with multiple micronutrients in Jordan.

Design: Retrospective analysis of the data from two repeated national cross-sectional panels of pre-school children.

Setting: The two surveys were conducted in 2007 and 2009, 16-20 months and 34-36 months, respectively, after implementation of wheat flour fortification with multiple micronutrients in Jordan. Anaemia was considered if $\mathrm{Hb}$ level was $<11 \mathrm{~g} / \mathrm{dl}$. An anaemia prevalence of $\geq 40 \%$ was considered a severe public health problem, while that of $20-39.9 \%$ was considered a moderate public health problem.

Subjects: A total of 3789 and 3447 children aged 6-59 months tested in 2007 and 2009, respectively.

Results: The prevalence of anaemia in pre-school children declined from $40.4 \%$ in 2007 to $33.9 \%$ in 2009 (adjusted $\mathrm{OR}=0.74 ; P<0.001$ ). The decline in the prevalence in 2009 as compared with 2007 was more pronounced among children aged $>24$ months ( -13.7 points), children living in urban areas ( -8.0 points), children from rich households ( $-9 \cdot 0$ points), children who had never been breastfed $(-17.0$ points $)$ and well-nourished children ( -6.8 points). In both surveys, presence of childhood anaemia was strongly associated with child age $\leq 24$ months, living in poor households, breast-feeding for $\geq 6$ months, malnourishment, poor maternal education and maternal anaemia.

Conclusions: The public health problem of childhood anaemia declined from severe in 2007 to moderate in 2009, after the implementation of wheat flour fortification with multiple micronutrients in Jordan.
\end{abstract}

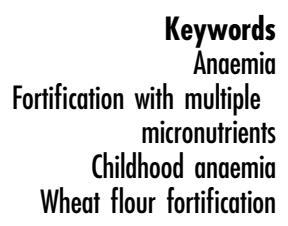

According to a global estimate based on data from 187 countries, the prevalence of anaemia has decreased from $40.2 \%$ in 1990 to $32.9 \%$ in $2010^{(1)}$. The decline in prevalence was in both sexes and for all severities of anaemia. However, measurements of total years of life lived with disability (YLD), reflecting population size and disability weights, showed that anaemia was responsible for 68.3 million YLD in 2010. This was greater than 65.5 million YLD in $1990^{(1)}$. The anaemia YLD in 2010 accounted for $8.8 \%$ of the total for all conditions, and was more than for major depression ( $8.2 \%)$, chronic respiratory diseases $(6 \cdot 3 \%)$ and injuries $(6.3 \%)^{(1)}$. The children under 5 years were the age group that showed the highest prevalence of anaemia; this age group was the only age group with increased anaemia prevalence from 1990 to $2010^{(1)}$.
Children of pre-school age are the most vulnerable to the detrimental long-term effects of anaemia ${ }^{(1)}$. Worldwide, it is estimated that 293.1 million (47.4\%) pre-school children are anaemic ${ }^{(2)}$. In developing countries 30-80\% of pre-school children are anaemic at 1 year of age ${ }^{(3)}$. In the Eastern Mediterranean Region, $46.7 \%$ ( 0.8 million) of pre-school children are anaemic, which is higher than the prevalence of $21.7 \%$ reported from Europe and $23.1 \%$ reported from the Western Pacific Region ${ }^{(2)}$. The WHO classifies the severity of the public health problem of anaemia in a population into severe ( $\geq 40 \%$ prevalence), moderate (20-39.9\% prevalence) or mild (5-19.9\% prevalence) based on the population anaemia prevalence, with a normal prevalence being defined as a prevalence of $\leq 4.9 \%{ }^{(4)}$. Out of 192 countries surveyed, the public health 
problem of anaemia in children of pre-school age was identified as severe, moderate and mild in sixty-nine, eighty-one and forty countries, respectively ${ }^{(2)}$.

Anaemia in children has significant public health consequences. It impairs the cognitive and physical development of the children and increases the mortality and morbidity rates in this population ${ }^{(5,6)}$. Breast-feeding and feeding practices, presence of infectious diseases ${ }^{(7,8)}$, presence of inherited conditions such as thalassaemia ${ }^{(9)}$, presence of environmental pollutants such as $\mathrm{Pb}^{(10)}$ and tobacco smoke ${ }^{(11)}$, nutritional status, mother's age at childbirth, maternal $\mathrm{Hb}$ and level of education ${ }^{(12,13)}$, economic status, sanitation, and also the geographic region of residence can contribute directly or indirectly to lowering of the $\mathrm{Hb}$ concentration among children ${ }^{(14)}$.

From 1990 to 2010, Fe deficiency was the top-ranking cause of anaemia in children of both sexes ${ }^{(1,15)}$. Other causes of anaemia in children and in all time periods in the 187 countries were hookworm, sickle cell disorders, thalassaemias, schistosomiasis and malaria. The lowest burden of anaemia from Fe deficiency was in North America $(2.9 \%)$ while its highest burden was in Central Asia (64.7\%), South Asia (54.8\%) and Andean Latin America $(62 \cdot 3 \%)^{(1)}$. Fe-deficiency anaemia can usually be prevented at a low cost and preventive programmes for this type of anaemia are recognized as among the most beneficial of public health interventions ${ }^{(6)}$. According to the WHO 2013 guidelines, targeted daily Fe supplementation should be considered a greater priority in high-risk populations such as children of pre-school age, women and high-prevalence populations ${ }^{(16)}$. Protein deficiency reduces the $\mathrm{Hb}$ concentration by $20 \%{ }^{(17)}$ and vitamin A deficiency and Fe-deficiency anaemia are known to usually coexist ${ }^{(18,19)}$. Food fortification is one of the well-recognized strategies for daily supplementation with multiple micronutrients including $\mathrm{Fe}$ to combat micronutrient deficiencies. It is described as one of the most cost-effective and sustainable strategies available to improve the micronutrient status at the population level ${ }^{(20)}$. Systematic reviews of data from randomized controlled clinical trials and quasi-experimental studies have shown a positive impact of the consumption of foods fortified with $\mathrm{Fe}$, folic acid and multiple micronutrients on the Fe status and $\mathrm{Hb}$ concentration ${ }^{(21-23)}$.

In Jordan, deficiencies of vitamin $\mathrm{A}, \mathrm{Fe}, \mathrm{Zn}$ and iodine have been identified as public health problems. To address these nutritional problems, the government has implemented different nationwide food fortification programmes, including fortification of salt and wheat flour ${ }^{(24)}$. Evidence is needed from developing countries on the impact of wheat flour fortification with multiple micronutrients on the health of children. The range of $\mathrm{Hb}$ values for non-anaemic persons overlap with values for persons with $\mathrm{Fe}$ deficiency, leading to misclassification of $\mathrm{Hb}$ concentration status. Therefore, although it is a widely used test, measuring $\mathrm{Hb}$ concentration should not be used as a sole indicator for Fe-deficiency anaemia ${ }^{(25)}$.
Regardless of $\mathrm{Fe}$ concentration, there are different factors playing a significant role in lowering or increasing the concentration of $\mathrm{Hb}$. These factors include biological variation, age and sex, pregnancy, higher altitudes, parasitic infections such as Plasmodium falciparum, chronic diseases such as HIV/AIDS, micronutrient deficiencies and smoking ${ }^{(25)}$. Smoking and higher altitudes are associated with a higher concentration of $\mathrm{Hb}^{(25)}$. In the present paper we describe the prevalence of anaemia and its correlates among pre-school children, assessed 16-20 months and 34-36 months after the initiation of wheat flour fortification with multiple micronutrients in Jordan, using two nationally representative samples collected in 2007 and 2009.

\section{Methods}

\section{Wheat flour fortification in Jordan}

The first nationwide fortification programme implemented in Jordan was the nationwide salt iodization programme launched in 1995. In 2002, the Jordanian Government mandated that all Mowahad wheat flour be fortified with only Fe and folic acid. In March 2006, the Mowahad wheat flour fortification programme was expanded to include multiple micronutrients and vitamins in addition to Fe and folic acid. In 2010, vitamin D was also added to the micronutrient premix formulation added to the wheat flour ${ }^{(24)}$. Mowahad wheat flour is the most widely consumed wheat flour in Jordan, accounting for more than $90 \%$ of all the wheat flour consumed in this country, and it is the only wheat flour subsidized by the government. In 2010 , the total annual cost to the government for procurement of the premix to be distributed to millers for fortifying wheat flour was approximately 1.2 million Jordanian Dinar (JD), or approximately 0.19 JD ( $\sim$ US 0.27) per capita ${ }^{(24)}$. Nutritional strengthening of wheat flour by the addition of more micronutrients in addition to $\mathrm{Fe}$ and folic acid in Jordan represents one of the most nutritionally comprehensive food fortification programmes in the world. The changes in the micronutrients added to Mowahad wheat flour from 2002 to 2011 are presented in Table $1^{(24)}$.

\section{Data sources}

We used data from two consecutive Jordan Population and Family Health Surveys carried out in 2007 (JPFHS-07) $^{(26)}$ and 2009 (JPFHS-09) $^{(27)}$ in Jordan. The Hb testing in JPFHS-07 was executed from June to November $2007^{(26)}$ during the summer and autumn seasons and that in JPFHS-09 was executed from October to December $2009^{(27)}$ during the autumn and winter seasons, which were 16-20 months and 34-36 months, respectively, after fortification of Mowahad wheat flour with multiple micronutrients was initiated (March 2006) in Jordan ${ }^{(24)}$. This 4-month difference in $\mathrm{Hb}$ testing for the two time survey points is accompanied with diversity in temperature and seasonal food items. In the summer season, the 
Table 1 Fortification of Mowahad wheat flour in 2002, 2006 and 2011 in Jordan

\begin{tabular}{|c|c|c|c|}
\hline \multirow[b]{2}{*}{ Nutrient } & \multicolumn{3}{|c|}{ Amount added (ppm) } \\
\hline & In 2002 & In 2006 & In 2011 \\
\hline $\mathrm{Fe}$ (ferrous sulfate) & $30 \cdot 00$ & $32 \cdot 25$ & $32 \cdot 25$ \\
\hline Zn (zinc oxide) & NA & $20 \cdot 00$ & $20 \cdot 00$ \\
\hline Vitamin $B_{1}$ (thiamin mononitrate) & NA & 3.575 & 3.575 \\
\hline Vitamin $B_{2}$ (riboflavin) & NA & 3.60 & 3.60 \\
\hline Vitamin $B_{3}$ (niacinamide) & NA & 35.00 & 35.00 \\
\hline Vitamin $B_{6}$ (pyridoxine) & NA & 4.40 & 4.40 \\
\hline Vitamin $B_{9}$ (folic acid) & 1.50 & 1.50 & 1.50 \\
\hline Vitamin $\mathrm{B}_{12}$ (vitamin $\left.\mathrm{B}_{12}, 0.1 \mathrm{wt} \%, \mathrm{WS}\right)$ & NA & 0.007 & 0.007 \\
\hline Vitamin A (vitamin A palmitate, SD) & NA & 1.50 & 1.50 \\
\hline Vitamin D (vitamin $D_{3}$, cholecalciferol) & NA & NA & 0.0145 \\
\hline
\end{tabular}

NA, not applicable (micronutrient was not added); WS, water-soluble; $\mathrm{SD}$, spray-dried.

relatively hot season, there are seasonal local fruits and vegetables such as tomatoes, melons and watermelons that are rich in water, whereas in the winter season, the relatively cold season, there is an increase in the production of leafy vegetables that are rich in vitamin $\mathrm{A}$, vitamin $\mathrm{B}_{6}$, folic acid, $\mathrm{Cu}$ and $\mathrm{Fe}$.

We chose to analyse data from the two JPFH surveys conducted in 2007 and 2009. The 2002 JPFHS was conducted 4-5 months after the start of the flour fortification programme with Fe and folic acid. The last JPFHS was conducted in 2012 after a reported stoppage and fluctuation in supplying $84.6 \%$ of wheat flour mills with micronutrient premix ${ }^{(24)}$.

The JPFHS was a nationally representative survey and part of the international Demographic and Health Surveys carried out to provide reliable estimates and up-to-date information about the demographic parameters and nutritional status of non-institutionalized women aged 15-49 years and children aged 6-59 months. The JPFHS followed a stratified two-stage cluster sampling design. In each survey, a representative sample of households was drawn from each of the twelve governorates independently. First, clusters were selected systematically as the primary sampling units with a probability proportional to the size of the primary sampling unit in each cluster. Second, household selection was carried out as an equal probability systematic selection of a fixed number of sixteen households from each primary sampling unit. More details of the sampling methodology are described elsewhere ${ }^{(27)}$.

Data were collected through face-to-face interviews carried out by trained interviewers using standardized questionnaires and methodologies. A total of 14564 and 14470 households, and a total of 10426 and 9650 children aged 0-59 months, were successfully surveyed in JPFHS-07 and JPFHS-09, respectively.

\section{Subjects}

The $\mathrm{Hb}$ concentrations in children aged 6-59 months and women aged 15-49 years were measured in a randomly selected sub-sample of the interviewed households in each of the two surveys. The subjects of the present study were restricted to children with valid $\mathrm{Hb}$ measurements, with a final unweighted sample size of 4124 and 3746 children from JPFHS-07 and JPFHS-09 (weighted sample size of 3789 and 3447), respectively.

\section{Dependent variable}

Blood drops collected by finger-prick were tested immediately for $\mathrm{Hb}$ concentration (HemoCue $\mathrm{AB}$, Sweden). Before classifying children by level of anaemia, an adjustment to sea-level equivalents was made by JPFHS using the Centers for Disease Control and Prevention formula ${ }^{(28)}$, given that $\mathrm{Hb}$ requirements differ substantially depending on altitude ${ }^{(29)}$. Children with a $\mathrm{Hb}$ level below $7 \cdot 0 \mathrm{~g} / \mathrm{dl}$ are classified as having severe anaemia, those with a level of $7 \cdot 0-9.9 \mathrm{~g} / \mathrm{dl}$ are classified as having moderate anaemia and those with a $\mathrm{Hb}$ level of $10 \cdot 0-10 \cdot 9 \mathrm{~g} / \mathrm{dl}$ are classified as having mild anaemia, according to criteria developed by the $\mathrm{WHO}^{(4)}$. The outcome variable was presence/absence of anaemia. Subjects were dichotomized based on a $\mathrm{Hb}$ cut-off level of $11 \mathrm{~g} / \mathrm{dl}(\mathrm{Hb}<11 \mathrm{~g} / \mathrm{dl}$, anaemia present; $\mathrm{Hb} \geq 11 \mathrm{~g} / \mathrm{dl}$, anaemia absent $)^{(4)}$.

\section{Independent variables}

Specific socio-economic and demographic variables of the children and mothers were used for the analyses. Data on the following characteristics were collected: age of the child in months ( $\leq 24,25-48$ or $>48$ months), sex (male or female), birth weight $(\leq 2500$ or $>2500 \mathrm{~g}$ ), place of residence (urban or rural), geographic location of residence (north, central or south) and duration of breast-feeding ( $\geq 6$ months, $<6$ months or never breast-fed). Children who were, at the time of the survey, on breast-feeding or breastfed for $>6$ months were regarded as breast-fed for $\geq 6$ months. The household wealth index as used an indicator of the family wealth status (very poor, relatively poor, middle-income household, relatively rich and very rich) ${ }^{(30)}$.

The children's nutritional status was assessed by measuring their height-for-age. A poor height-for-age index reflects the long-term, cumulative effects of inadequate nutrition, poor health or both. For children aged $>24$ months, their standing height was measured, whereas for those aged $<24$ months, their recumbent length was measured using the Shorr height board. As compared with the median of the reference population, children with a height-for-age index below -2 SD were categorized as stunted/chronically malnourished, those with an index of -2 to -2.99 SD were categorized as showing moderately stunted growth, and those below $-3 \mathrm{SD}$ as showing severely stunted growth ${ }^{(31)}$.

Mother's age (15-24, 25-34 or 35-49 years) and level of education (primary and below, secondary or higher education) were classified into three groups. To be comparable with respect to sea level ${ }^{(29)}$ and smoking status ${ }^{(32)}$, the measured maternal $\mathrm{Hb}$ concentration was adjusted by 
the JPFHS using the Centers for Disease Control and Prevention formulas ${ }^{(28,33)}$. According to WHO criteria, nonpregnant and pregnant mothers with a $\mathrm{Hb}$ level of $<11.9 \mathrm{~g} / \mathrm{dl}$ and $<10.9 \mathrm{~g} / \mathrm{dl}$, respectively, were defined as anaemic ${ }^{(4)}$. BMI was measured to evaluate the mothers' nutritional status, and the mothers were categorized based on the standard WHO classification into underweight (BMI $<18.5$ $\left.\mathrm{kg} / \mathrm{m}^{2}\right)$, normal weight $\left(\mathrm{BMI}=18.5-24.9 \mathrm{~kg} / \mathrm{m}^{2}\right)$ or overweight (BMI $\geq 25.0 \mathrm{~kg} / \mathrm{m}^{2}$ ). Tobacco smoking was recorded as yes or no, and the mothers were also classified based on the type of tobacco smoked into either exclusive waterpipe or exclusive cigarette smokers.

\section{Statistical analyses}

Descriptive statistics are presented as weighted percentages for the measured variables and the differences in the percentage of children for each measured covariate between the JPFHS-07 and JPFHS-09 were assessed by the $\chi^{2}$ test. The difference in the weighted mean Hb level in the surveyed children between JPFHS-07 and JPFHS-09 was assessed by the Student's $t$ test. We estimated the absolute difference in the weighted prevalence of anaemia for each measured covariate between the JPFHS-07 and JPFHS-09 by the $\chi^{2}$ test. Differences in the percentage of weighted anaemia between sub-categories of each measured covariate were assessed by the $\chi^{2}$ test after pooling the two data sets. A sampling weight was developed by JPFHS according to the sample allocation. Weighted analysis was conducted to adjust for the complex household survey design including potential over-sampling or under-sampling and to ensure the actual representativeness of the survey results at the national level as well as at the cluster level.

After excluding 268 children with missing information on height and forty-five children with missing information on $\mathrm{Hb}$ concentration of the mother in both surveys, multivariate models including only children for whom full information about the measured characteristics was available were performed to estimate the prevalence of childhood anaemia after adjustments for the effects of the survey phase, children's characteristics and mothers' characteristics in the overall population of children and by the survey phase. To adjust for potential confounders, all variables that showed a significant relationship with anaemia at $P \leq 0.05$ in the bivariate analysis were included in the multivariate models, simultaneously. Absence of multicollinearity between independent variables was confirmed using the variance inflation factor. Results were reported in terms of crude and adjusted odds ratios to assess the strength of the association between the predictors and anaemia, and the 95\% confidence intervals were calculated for significance testing. Analyses were performed using the statistical software package IBM SPSS Statistics version 18.0. A two-tailed $P$ value of $\leq 0.05$ was considered as denoting statistical significance.

\section{Results}

In both surveys, the most represented age group was children aged 25-48 months (44.9\%); about $83 \%$ of the children were born with a birth weight of $>2500 \mathrm{~g}$ and were from urban settings, without any significant differences in these three characteristics between the two surveys. The percentage of children breast-fed for $<6$ months increased from $16.6 \%$ in JPFHS-07 to $19.3 \%$ in JPFHS-09. The percentage of children living in very poor households declined from $27.5 \%$ in JPFHS-07 to $24.2 \%$ in JPFHS-09, with a corresponding increase in the percentage of children living in relatively rich households from $16 \cdot 2 \%$ to $19.1 \%$. The percentage of moderately or severely stunted children declined by more than a half, from $14.7 \%$ in JPFHS-07 to $8.2 \%$ in JPFHS-09 (Table 2).

On average, the children's mean $\mathrm{Hb}$ level was $11.37 \mathrm{~g} / \mathrm{dl}$ (range: $8 \cdot 0-15.0 \mathrm{~g} / \mathrm{dl}$ ), with a significant increase in the overall mean by $2 \cdot 08 \mathrm{~g} / \mathrm{dl}$ from JPFHS-07 to JPFHS-09 $(P<0.001)$. Of the total sample, $37.3 \%, 15.5 \%$ and $21.7 \%$ of the children were severely anaemic, moderately anaemic and mildly anaemic, respectively. The most significant decline in the prevalence of anaemia was found in children with mild anaemia (from $24.3 \%$ in JPFHS-07 to $18.9 \%$ in JPFHS-09; $P<0.001)$ during the study period (data not shown). The decline was across all the measured characteristics of the children, except among children who lived in rural areas, in the north and south regions of the country, and those with moderate and severe growth stunting. The decline was higher among children aged $25-48$ months $(-10 \cdot 6 \%)$, males $(-7.2 \%)$, children with a birth weight of $>2500 \mathrm{~g}(-7 \cdot 6 \%)$, children from urban areas $(-8.0 \%)$, children from the central regions $(-14.0 \%)$, children belonging to middle-income households $(-7 \cdot 1 \%)$ and children who had never been breast-fed (-17.0\%). The prevalence of anaemia was not associated with sex, birth weight or place of residence in either survey (Table 2).

Table 3 shows a comparison of the mother's characteristics and the prevalence of anaemia among the children in JPFHS-07 and JPFHS-09. The percentage of mothers with a higher level of education increased from $27.5 \%$ in JPFHS-07 to $30.2 \%$ in JPFHS-09. Maternal anaemia declined by $5.8 \%$, while the percentage of overweight women increased by $6 \cdot 2 \%$ from JPFHS-07 to JPFHS-09 $(P<0 \cdot 001)$. Anaemia among children declined across all mothers' ages and education groups. The anaemia prevalence declined by $7 \cdot 4 \%$ among children living with mothers aged $15-24$ years and by $8.8 \%$ among children born to mothers with a higher level of education. The anaemia prevalence also declined by $21.9 \%$ among children born to tobacco-smoking mothers.

After pooling the two data sets, children tested in JPFHS-09 were $25 \%$ less likely to show a $\mathrm{Hb}$ level indicative of anaemia (adjusted OR $=0 \cdot 75 ; 95 \%$ CI 0.68, 0.83; $P<0.001)$ than those tested in JPFHS-07 (data not shown). 
Table 2 Descriptive data and prevalence of anaemia among children of pre-school age in Jordan by the children's characteristics, stratified by the survey phase

\begin{tabular}{|c|c|c|c|c|c|c|c|c|}
\hline \multirow[b]{2}{*}{ Children's characteristics } & \multicolumn{2}{|c|}{ JPFHS-07 (N 3789) } & \multicolumn{2}{|c|}{ JPFHS-09 (N 3447) } & \multirow[b]{2}{*}{$\begin{array}{c}P \\
\text { value† }\end{array}$} & \multirow[b]{2}{*}{$\begin{array}{l}\text { Absolute } \\
\text { differenceł }\end{array}$} & \multicolumn{2}{|c|}{$\begin{array}{l}\text { JPFHS-07 and JPFHS-09 } \\
(N 7236)\end{array}$} \\
\hline & $\begin{array}{l}\% \text { of } \\
\text { children }\end{array}$ & $\begin{array}{c}\% \text { of } \\
\text { anaemia }\end{array}$ & $\begin{array}{l}\% \text { of } \\
\text { children }\end{array}$ & $\begin{array}{c}\% \text { of } \\
\text { anaemia }\end{array}$ & & & $\begin{array}{l}\% \text { of } \\
\text { children }\end{array}$ & $\begin{array}{c}\% \text { of } \\
\text { anaemia }\end{array}$ \\
\hline $\begin{array}{l}\text { All } \\
\text { Age (months) }\end{array}$ & $100 \cdot 0$ & $40 \cdot 4$ & $100 \cdot 0$ & 33.9 & $\begin{array}{r}<0.001 \\
0.097\end{array}$ & $-6 \cdot 5$ & $100 \cdot 0$ & $37 \cdot 3$ \\
\hline$\leq 24$ & $35 \cdot 0$ & 53.8 & $37 \cdot 0$ & $49 \cdot 4$ & & $-4 \cdot 3$ & $36 \cdot 0$ & $51 \cdot 7$ \\
\hline $25-48$ & $45 \cdot 1$ & $36 \cdot 6$ & $44 \cdot 7$ & $26 \cdot 0$ & & $-10 \cdot 6$ & 44.9 & 31.6 \\
\hline $\begin{array}{l}>48 \\
P \text { value§ }\end{array}$ & $19 \cdot 9$ & $\begin{array}{l}25 \cdot 2 \\
<0.001\end{array}$ & $18 \cdot 3$ & $\begin{array}{l}22 \cdot 1 \\
<0.001\end{array}$ & & $-3 \cdot 1$ & $19 \cdot 2$ & $\begin{array}{l}23.8 \\
<0.001\end{array}$ \\
\hline Sex & & & & & 0.020 & & & \\
\hline Male & 49.5 & $41 \cdot 2$ & $52 \cdot 2$ & 34.0 & & $-7 \cdot 2$ & $50 \cdot 8$ & 37.7 \\
\hline $\begin{array}{l}\text { Female } \\
P \text { value§ }\end{array}$ & $50 \cdot 5$ & $\begin{array}{c}39.6 \\
0.29\end{array}$ & $47 \cdot 8$ & $\begin{array}{l}33.8 \\
0.92\end{array}$ & & $-5 \cdot 8$ & $49 \cdot 2$ & $\begin{array}{l}36.9 \\
0.51\end{array}$ \\
\hline Birth weight (g) & & & & & 0.321 & & & \\
\hline$\leq 2500$ & $17 \cdot 1$ & $36 \cdot 7$ & $16 \cdot 3$ & $36 \cdot 0$ & & -0.7 & $16 \cdot 7$ & $36 \cdot 4$ \\
\hline $\begin{array}{l}>2500 \\
P \text { value }\end{array}$ & $82 \cdot 1$ & $\begin{array}{l}41.0 \\
0.045\end{array}$ & $83 \cdot 2$ & $\begin{array}{c}33.4 \\
0.23\end{array}$ & & $-7 \cdot 6$ & $82 \cdot 7$ & $\begin{array}{l}37.3 \\
0.56\end{array}$ \\
\hline Missing & 0.07 & & 0.05 & & & & 0.06 & \\
\hline Place of residence & & & & & 0.174 & & & \\
\hline Urban & 83.5 & $40 \cdot 7$ & $82 \cdot 3$ & $32 \cdot 7$ & & $-8 \cdot 0$ & $82 \cdot 9$ & $36 \cdot 9$ \\
\hline $\begin{array}{l}\text { Rural } \\
P \text { value§ }\end{array}$ & $16 \cdot 5$ & $\begin{array}{l}38 \cdot 7 \\
0.34\end{array}$ & $17 \cdot 7$ & $\begin{array}{l}39.8 \\
0.001\end{array}$ & & $1 \cdot 1$ & $17 \cdot 1$ & $\begin{array}{l}39 \cdot 2 \\
0.12\end{array}$ \\
\hline \multicolumn{9}{|l|}{ Geographic location } \\
\hline North & $28 \cdot 2$ & $31 \cdot 0$ & $31 \cdot 8$ & $36 \cdot 0$ & & $5 \cdot 0$ & 29.9 & 33.6 \\
\hline Central & $62 \cdot 3$ & $45 \cdot 6$ & $58 \cdot 1$ & $31 \cdot 6$ & & $-14 \cdot 0$ & $60 \cdot 3$ & $39 \cdot 2$ \\
\hline South & 9.5 & $33 \cdot 7$ & $10 \cdot 1$ & $40 \cdot 7$ & & $7 \cdot 0$ & 9.8 & $37 \cdot 1$ \\
\hline$P$ value§ & & $<0.001$ & & $<0.001$ & & & & $<0.001$ \\
\hline Duration of breast-feeding & & & & & $<0.001$ & & & \\
\hline$\geq 6$ months & $77 \cdot 2$ & $40 \cdot 9$ & $76 \cdot 6$ & $36 \cdot 0$ & & -4.9 & $77 \cdot 0$ & 38.6 \\
\hline$<6$ months & $16 \cdot 6$ & $36 \cdot 0$ & $19 \cdot 3$ & $27 \cdot 0$ & & -9.0 & $17 \cdot 9$ & 31.4 \\
\hline $\begin{array}{l}\text { Never } \\
P \text { value§ }\end{array}$ & $6 \cdot 2$ & $\begin{array}{l}45.1 \\
<0.025\end{array}$ & $4 \cdot 0$ & $\begin{array}{l}28 \cdot 1 \\
<0.001\end{array}$ & & $-17 \cdot 0$ & $5 \cdot 1$ & $\begin{array}{l}38.7 \\
<0.001\end{array}$ \\
\hline Wealth index & & & & & $<0.001$ & & & \\
\hline Very poor & 27.5 & 43.7 & $24 \cdot 2$ & $42 \cdot 3$ & & $-1 \cdot 4$ & $25 \cdot 9$ & $43 \cdot 1$ \\
\hline Relatively poor & $23 \cdot 6$ & $40 \cdot 8$ & $26 \cdot 9$ & $36 \cdot 5$ & & $-4 \cdot 3$ & $25 \cdot 2$ & $38 \cdot 6$ \\
\hline $\begin{array}{l}\text { Middle-income } \\
\text { household }\end{array}$ & 21.4 & 38.5 & $19 \cdot 8$ & 31.4 & & $-7 \cdot 1$ & $20 \cdot 6$ & $35 \cdot 2$ \\
\hline Relatively rich & $16 \cdot 2$ & 33.0 & $19 \cdot 1$ & 29.5 & & $-3 \cdot 5$ & $17 \cdot 6$ & $31 \cdot 2$ \\
\hline $\begin{array}{l}\text { Very rich } \\
P \text { value }\end{array}$ & 11.3 & $\begin{array}{l}45.5 \\
<0.001\end{array}$ & $10 \cdot 0$ & $\begin{array}{l}20.0 \\
<0.001\end{array}$ & & $-5 \cdot 5$ & $10 \cdot 7$ & $\begin{array}{l}34.1 \\
<0.001\end{array}$ \\
\hline Stunting of growth & & & & & $<0.001$ & & & \\
\hline No growth stunting & $85 \cdot 3$ & 39.6 & $91 \cdot 8$ & $32 \cdot 8$ & & $-6 \cdot 8$ & 88.5 & $36 \cdot 2$ \\
\hline $\begin{array}{l}\text { Moderate growth } \\
\text { stunting }\end{array}$ & $9 \cdot 1$ & $42 \cdot 0$ & 6.5 & $45 \cdot 5$ & & 3.5 & $7 \cdot 8$ & $43 \cdot 5$ \\
\hline $\begin{array}{l}\text { Severe growth stunting } \\
P \text { value§ }\end{array}$ & $5 \cdot 6$ & $\begin{array}{l}50.0 \\
0.012\end{array}$ & $1 \cdot 7$ & $\begin{array}{l}50.9 \\
<0.001\end{array}$ & & 0.9 & $3 \cdot 7$ & $\begin{array}{l}50.0 \\
<0.001\end{array}$ \\
\hline Missing & $5 \cdot 9$ & & $1 \cdot 3$ & & & & $3 \cdot 7$ & \\
\hline
\end{tabular}

JPFHS, Jordan Population and Family Health Survey; $N$, weighted number of children.

$\dagger P$ value from $X^{2}$ test for the difference in the percentage of children according to children's characteristics by the survey phase.

$\ddagger$ Absolute difference in the occurrence of anaemia between the two surveys (prevalence in 2007 subtracted from prevalence in 2009 ).

$\S P$ value from $X^{2}$ test for the occurrence of anaemia among children according to children's characteristics in each survey phase.

Table 4 shows the adjusted OR of childhood anaemia by the children's characteristics. In both surveys, childhood anaemia was positively associated with age of the child $\leq 24$ months, living in the central region of the country, breast-fed for $\geq 6$ months, living in a family of relatively lower wealth status and malnutrition. Chronic malnutrition was the characteristic that showed the greatest positive correlation with the presence of anaemia.

Table 5 shows the adjusted effect of the mothers' characteristics on childhood anaemia. Anaemia among children was positively associated with increasing mother's age, maternal anaemia and below-normal body weight of the mothers. Mother's exposure to tobacco smoke was not associated with the prevalence of childhood anaemia. Living with an anaemic (adjusted $\mathrm{OR}=$ 1.69) or an underweight mother (adjusted $\mathrm{OR}=1.75$ ) showed the strongest positive association with the prevalence of childhood anaemia $(P<0 \cdot 01)$.

\section{Discussion}

The prevalence of anaemia in pre-school children aged 6-59 months declined significantly within the 2-year study 
Table 3 Descriptive data and prevalence of anaemia among children of pre-school age in Jordan by the mothers' characteristics, stratified by the survey phase

\begin{tabular}{|c|c|c|c|c|c|c|c|c|}
\hline \multirow[b]{2}{*}{$\begin{array}{l}\text { Mothers' } \\
\text { characteristics }\end{array}$} & \multicolumn{2}{|c|}{ JPFHS-07 (N 3789) } & \multicolumn{2}{|c|}{ JPFHS-09 (N 3447) } & \multirow[b]{2}{*}{$\begin{array}{c}P \\
\text { value† }\end{array}$} & \multirow[b]{2}{*}{$\begin{array}{l}\text { Absolute } \\
\text { differencef }\end{array}$} & \multicolumn{2}{|c|}{$\begin{array}{c}\text { JPFHS-07 and JPFHS-09 } \\
(N \text { 7236) }\end{array}$} \\
\hline & $\begin{array}{c}\% \text { of } \\
\text { children }\end{array}$ & $\begin{array}{c}\% \text { of } \\
\text { anaemia }\end{array}$ & $\begin{array}{l}\% \text { of } \\
\text { children }\end{array}$ & $\begin{array}{c}\% \text { of } \\
\text { anaemia }\end{array}$ & & & $\begin{array}{c}\% \text { of } \\
\text { children }\end{array}$ & $\begin{array}{c}\% \text { of } \\
\text { anaemia }\end{array}$ \\
\hline Age (years) & & & & & 0.336 & & & \\
\hline $15-24$ & $16 \cdot 7$ & 41.9 & $15 \cdot 5$ & 34.5 & & -7.4 & $16 \cdot 1$ & 38.6 \\
\hline $25-34$ & $46 \cdot 5$ & $40 \cdot 2$ & $56 \cdot 8$ & 34.2 & & $-6 \cdot 0$ & $56 \cdot 5$ & $37 \cdot 3$ \\
\hline $\begin{array}{l}35-49 \\
P \text { value§ }\end{array}$ & $27 \cdot 0$ & $\begin{array}{l}39.8 \\
0.660\end{array}$ & $27 \cdot 8$ & $\begin{array}{l}33.0 \\
0.778\end{array}$ & & $-6 \cdot 8$ & $27 \cdot 4$ & $\begin{array}{l}36.5 \\
0.508\end{array}$ \\
\hline Education & & & & & 0.041 & & & \\
\hline Primary or below & 8.6 & $46 \cdot 5$ & $8 \cdot 1$ & $40 \cdot 3$ & & $-6 \cdot 2$ & $8 \cdot 3$ & 43.5 \\
\hline Secondary & 63.9 & $40 \cdot 3$ & $61 \cdot 8$ & 35.1 & & $-5 \cdot 2$ & 62.9 & 37.9 \\
\hline Higher & $27 \cdot 5$ & $38 \cdot 6$ & $30 \cdot 2$ & $29 \cdot 8$ & & $-8 \cdot 8$ & 28.8 & $34 \cdot 2$ \\
\hline$P$ value§ & & 0.041 & & 0.001 & & & & $<0.001$ \\
\hline Maternal anaemia & & & & & $<0.001$ & & & \\
\hline No & $60 \cdot 6$ & $36 \cdot 5$ & 65.6 & $30 \cdot 3$ & & $-6 \cdot 2$ & $62 \cdot 4$ & $32 \cdot 8$ \\
\hline Yes & 39.2 & $46 \cdot 3$ & 33.4 & 41.0 & & $-5 \cdot 3$ & $36 \cdot 3$ & 43.3 \\
\hline$P$ value $\S$ & & $<0.001$ & & $<0.001$ & & & & $<0.001$ \\
\hline Missing & 0.04 & & 0.09 & & & & 0.06 & \\
\hline Mother's BMI $\left(\mathrm{kg} / \mathrm{m}^{2}\right)$ & & & & & $<0.001$ & & & \\
\hline Normal (18.5-24.9) & 37.6 & $45 \cdot 3$ & 31.6 & $36 \cdot 1$ & & -9.2 & 34.7 & 41.3 \\
\hline $\begin{array}{l}\text { Underweight } \\
(<18.5)\end{array}$ & $2 \cdot 0$ & $56 \cdot 2$ & $1 \cdot 7$ & $44 \cdot 1$ & & $-12 \cdot 1$ & 1.8 & $51 \cdot 1$ \\
\hline $\begin{array}{l}\text { Overweight }(\geq 25 \cdot 0) \\
P \text { value§ }\end{array}$ & $60 \cdot 5$ & $\begin{array}{l}36 \cdot 8 \\
<0.001\end{array}$ & $66 \cdot 7$ & $\begin{array}{c}32.6 \\
0.037\end{array}$ & & $-4 \cdot 2$ & 63.4 & $\begin{array}{l}34.7 \\
<0.001\end{array}$ \\
\hline Missing & 0.07 & & 0.01 & & & & 0.04 & \\
\hline Tobacco smoking & & & & & 0.983 & & & \\
\hline No & $90 \cdot 8$ & 39.9 & $90 \cdot 8$ & $35 \cdot 0$ & & -4.9 & $90 \cdot 8$ & 37.6 \\
\hline Yes & $9 \cdot 2$ & $45 \cdot 1$ & $9 \cdot 2$ & $23 \cdot 2$ & & -21.9 & $9 \cdot 2$ & $34 \cdot 6$ \\
\hline$P$ value§ & & 0.053 & & $<0.001$ & & & & 0.127 \\
\hline Waterpipe smoking & & & & & 0.697 & & & \\
\hline No & $96 \cdot 2$ & $40 \cdot 2$ & $96 \cdot 0$ & 34.3 & & -5.9 & $96 \cdot 1$ & 37.4 \\
\hline Yes & $3 \cdot 8$ & 44.5 & 4.0 & $25 \cdot 2$ & & $-19 \cdot 3$ & 3.9 & $35 \cdot 1$ \\
\hline$P$ value§ & & 0.291 & & 0.022 & & & & 0.434 \\
\hline Cigarette smoking & & & & & 0.626 & & & \\
\hline No & $92 \cdot 8$ & $40 \cdot 0$ & 93.1 & 34.7 & & $-5 \cdot 3$ & 92.9 & 37.5 \\
\hline Yes & $7 \cdot 2$ & 44.5 & 6.9 & $23 \cdot 8$ & & $-20 \cdot 7$ & $7 \cdot 1$ & 34.9 \\
\hline$P$ value§ & & 0.147 & & 0.001 & & & & 0.245 \\
\hline
\end{tabular}

JPFHS, Jordan Population and Family Health Survey; $N$, weighted number of total children.

$\dagger P$ value from $X^{2}$ test assessing the difference in the percentage of children according to mothers' characteristics by the survey phase.

†Absolute difference in the occurrence of anaemia between the two surveys (prevalence in 2007 subtracted from prevalence in 2009 ).

$\S P$ value from $X^{2}$ test assessing difference in the occurrence of anaemia among children according to mothers' characteristics in each survey phase.

period in Jordan, from $40.4 \%$ in 2007 to $33.9 \%$ in 2009 , after the implementation of fortification of wheat flour with multiple micronutrients. The decline was more pronounced in children with better socio-economic and nutritional status. Furthermore, the decline was apparent across all of the measured characteristics of the children, except for residence in a rural area, residence in the north and south regions of the country, and moderate or severe malnutrition. The most pronounced decline was seen in children aged 25-48 months, children living in urban areas or the central region of the country, children who had never been breast-fed and children who did not show stunted growth.

The positive impact of food fortification on the prevention and control of micronutrient deficiencies has been widely discussed $^{(6,15)}$. A recent systematic review of 201 studies conducted on children and women (including 125 randomized controlled trials and seventy-six quasiexperimental studies) reported that fortification of foods with multiple micronutrients was associated with increased serum micronutrient and $\mathrm{Hb}$ concentrations among children ${ }^{(21)}$. Another systematic review carried out in Brazil of the data from studies conducted pre- and postflour fortification with folic acid showed that the serum folate concentrations increased by $57 \%$ in healthy children and $174 \%$ in adults ${ }^{(34)}$. In Costa Rica, the prevalence of anaemia in children decreased from $19.3 \%$ to $4.0 \%$ and that of Fe deficiency declined from $26.9 \%$ to $6.8 \%$ after mass fortification of staple foods and condiments with multiple micronutrients ${ }^{(35)}$. Among pregnant women assisted in primary health-care services in Maringá municipality in southern Brazil, as one of the vulnerable groups for anaemia, a study found that women tested after flour fortification had a higher $\mathrm{Hb}$ level than those tested before flour fortification with $\mathrm{Fe}$, after women who were receiving Fe supplementation were excluded ${ }^{(36)}$. Another large-scale population-based study using repeated crosssectional samples of 12119 pregnant women in five 
Table 4 Adjusted odds ratios $\dagger$ of childhood anaemia among children of pre-school age in Jordan by the children's characteristics and by the survey phase

\begin{tabular}{|c|c|c|c|c|c|c|}
\hline \multirow[b]{3}{*}{ Children's characteristics } & \multicolumn{4}{|c|}{ Survey phase } & & \\
\hline & \multicolumn{2}{|c|}{ JPFHS-07 } & \multicolumn{2}{|c|}{ JPFHS-09 } & \multicolumn{2}{|c|}{ JPFHS-07 and JPFHS-09 } \\
\hline & Adjusted OR & $95 \% \mathrm{Cl}$ & Adjusted OR & $95 \% \mathrm{Cl}$ & Adjusted OR & $95 \% \mathrm{Cl}$ \\
\hline \multicolumn{7}{|l|}{ Age (months) } \\
\hline$\leq 24$ & 1.00 & Ref. & 1.00 & Ref. & 1.00 & Ref. \\
\hline $25-48$ & $0.53^{\star \star \star}$ & $0.45,0.63$ & $0.42^{\star \star \star}$ & $0.35,0.51$ & $0.48^{\star \star \star}$ & $0.43,0.55$ \\
\hline$>48$ & $0.29^{\star \star \star}$ & $0.24,0.37$ & $0.33^{\star \star \star}$ & $0.26,0.42$ & $0.32^{\star \star \star}$ & $0.27,0.37$ \\
\hline \multicolumn{7}{|l|}{ Sex } \\
\hline Male & 1.00 & & 1.00 & Ref. & 1.00 & Ref. \\
\hline Female & 0.93 & $0.81,1.07$ & 1.06 & $0.91,1.23$ & 0.98 & $0.88,1.01$ \\
\hline \multicolumn{7}{|l|}{ Birth weight (g) } \\
\hline$\leq 2500$ & 1.00 & Ref. & 1.00 & Ref. & 1.00 & Ref. \\
\hline$>2500$ & $1 \cdot 32^{\star \star}$ & $1.10,1.60$ & 0.88 & $0.72,1.08$ & $1 \cdot 10$ & $0.96,1.27$ \\
\hline \multicolumn{7}{|l|}{ Place of residence } \\
\hline Urban & 1.00 & Ref. & 1.00 & Ref. & 1.00 & Ref. \\
\hline Rural & $0.80^{*}$ & $0.66,0.96$ & $1 \cdot 19$ & $0.97,1.46$ & 0.99 & $0.87,1.14$ \\
\hline \multicolumn{7}{|l|}{ Geographic location } \\
\hline North & 1.00 & Ref. & 1.00 & Ref. & 1.00 & Ref. \\
\hline Central & $1.99^{\star \star \star}$ & $1 \cdot 67,2 \cdot 37$ & 0.96 & $0.80,1.14$ & $1.40^{\star \star *}$ & $1.23,1.58$ \\
\hline South & 1.19 & $0.89,1.57$ & 1.20 & $0.92,1.58$ & 1.19 & $0.98,1.44$ \\
\hline \multicolumn{7}{|l|}{ Duration of breast-feeding } \\
\hline$\geq 6$ months & 1.00 & Ref. & 1.00 & Ref. & 1.00 & Ref. \\
\hline$<6$ months & $0.77^{\star \star}$ & $0.63,0.92$ & $0.70^{\star \star *}$ & $0.57,0.85$ & $0.73^{\star \star \star}$ & $0.63,0.83$ \\
\hline Never & 1.33 & $0.98,1.78$ & $0.63^{*}$ & $0.41,0.94$ & 1.08 & $0.85,1.37$ \\
\hline \multicolumn{7}{|l|}{ Wealth index } \\
\hline Very poor & 1.00 & Ref. & 1.00 & Ref. & 1.00 & Ref. \\
\hline Relatively poor & 0.88 & $0.73,1.07$ & 0.82 & $0.67,1.02$ & $0.85^{\star}$ & $0.74,0.98$ \\
\hline Middle-income household & $0.78^{*}$ & $0.64,0.94$ & $0.61^{\star \star \star}$ & $0.49,0.77$ & $0.70^{\star \star \star}$ & $0.6,0.80$ \\
\hline Relatively rich & $0.59^{\star \star \star}$ & $0.48,0.73$ & $0.60^{\star \star \star}$ & $0.47,0.76$ & $0.60^{\star \star \star}$ & $0.51,0.70$ \\
\hline Very rich & 1.14 & $0.90,1.46$ & $0.35^{\star \star *}$ & $0.25,0.48$ & $0.71^{\star \star}$ & $0.59,0.86$ \\
\hline \multicolumn{7}{|l|}{ Stunting } \\
\hline No growth stunting & 1.00 & Ref. & 1.00 & Ref. & 1.00 & Ref. \\
\hline Moderate growth stunting & 1.25 & $0.98,1.60$ & $1.69^{\star \star \star}$ & $1 \cdot 26,2 \cdot 26$ & $1.42^{\star \star \star}$ & $1.19,1.72$ \\
\hline Severe growth stunting & $1 \cdot 71^{\star \star \star}$ & $1 \cdot 27,2 \cdot 31$ & $1.90^{\star}$ & $1.08,3.37$ & $1 \cdot 72^{\star \star \star}$ & $1.32,2.24$ \\
\hline
\end{tabular}

JPFHS, Jordan Population and Family Health Survey; Ref., reference category.

${ }^{\star} P<0 \cdot 05,{ }^{\star \star} P<0 \cdot 01,{ }^{\star \star \star} P<0 \cdot 001$.

†Adjusted OR include 6924 children with full information about all variables included in the multivariate model (in 2007, $n$ 3538; in 2009, $n$ 3386).

Brazilian regions showed that the prevalence of anaemia declined from $25 \%$ pre-fortification to $20 \%(P<0 \cdot 001)$ among tested pregnant women at least 1 year after the mandatory fortification of wheat and corn flour with $\mathrm{Fe}^{(37)}$. In the present study, the observed improvement of nutritional status over time was in parallel with a decline in the severity of the public health problem of anaemia in children of pre-school age from severe to moderate. An expanded fortification of Mowahad wheat flour with multiple micronutrients initiated in 2006 was consistent with reduction of the prevalence of anaemia.

Different countries in the Middle East and North Africa region have implemented wheat flour fortification programmes. In the 1990s, Oman, Bahrain, Iraq, Libya and Iran began fortifying wheat flour with only Fe and folic $\operatorname{acid}^{(38)}$. In the present study, although a decline was observed in the prevalence of childhood anaemia in Jordan over the 2-year study period, the prevalence in the last survey carried out in 2009 was still higher than that among pre-school children in many other countries in the region, including Bahrain (24.7\%), Cyprus (18.6\%), Egypt (29.9\%), Lebanon (28.3\%) and Qatar $(26 \cdot 2 \%)^{(2)}$.
Nevertheless, findings from the current study encourage continuation of fortifying wheat flour with multiple micronutrients in addition to Fe and folic acid in Jordan.

Different factors were associated with the low Hb concentrations found among pre-school children. The severity of anaemia varied among different subgroups of age: younger children were at a higher risk of developing anaemia, with children aged $\leq 24$ months at twofold higher risk of anaemia than children aged $25-48$ months. This is consistent with the findings of numerous previous studies ${ }^{(39-42)}$. The prevalence of anaemia among children tends to decrease linearly from 2 years of age ${ }^{(40,41)}$. In the first 2 years of life, growth and development occur at an accelerated pace in children and they need higher amounts of $\mathrm{Fe}^{(43,44)}$. After the sixth month, Fe stores are depleted and nutrition plays a crucial role in the supply of this mineral to the infant. Older children, as a result of growth and development, obtain adequate amounts of $\mathrm{Fe}$ quite easily from the consumption of different foods ${ }^{(42-44)}$.

The decline in the prevalence of childhood anaemia was associated with the place of residence and region. There was a decline over time in the prevalence of 
Table 5 Adjusted odds ratios $\dagger$ of childhood anaemia among children of pre-school age in Jordan by the mothers' characteristics and by the survey phase

\begin{tabular}{|c|c|c|c|c|c|c|}
\hline \multirow[b]{3}{*}{ Mothers' characteristics } & \multicolumn{4}{|c|}{ Survey phase } & & \\
\hline & \multicolumn{2}{|c|}{ JPFHS-07 } & \multicolumn{2}{|c|}{ JPFHS-09 } & \multicolumn{2}{|c|}{ JPFHS-07 and JPFHS-09 } \\
\hline & Adjusted OR & $95 \% \mathrm{Cl}$ & Adjusted OR & $95 \% \mathrm{Cl}$ & Adjusted OR & $95 \% \mathrm{Cl}$ \\
\hline \multicolumn{7}{|l|}{ Age (years) } \\
\hline $15-24$ & 1.00 & Ref. & 1.00 & Ref. & 1.00 & Ref. \\
\hline $25-34$ & 1.19 & $0.97,1.46$ & $1.32^{*}$ & $1.05,1.65$ & $1.22^{\star *}$ & $1.05,1.42$ \\
\hline $35-49$ & $1 \cdot 28^{*}$ & $1.01,1.63$ & $1.29^{*}$ & $1.00,1.67$ & $1 \cdot 30^{\star \star}$ & $1 \cdot 10,1.55$ \\
\hline \multicolumn{7}{|l|}{ Education } \\
\hline Primary or below & 1.00 & Ref. & 1.00 & Ref. & 1.00 & Ref. \\
\hline Secondary & 0.81 & $0.62,1.06$ & 1.02 & $0.77,1.37$ & 0.91 & $0.75,1.11$ \\
\hline Higher & 0.76 & $0.56,1.03$ & 0.92 & $0.67,1.27$ & 0.85 & $0.68,1.05$ \\
\hline \multicolumn{7}{|l|}{ Maternal anaemia } \\
\hline No & 1.00 & Ref. & 1.00 & Ref. & 1.00 & Ref. \\
\hline Yes & $1.74^{\star \star \star}$ & $1 \cdot 33,2 \cdot 28$ & $1.53^{\star \star}$ & $1 \cdot 11,2.09$ & $1.69^{\star \star \star}$ & $1.38,2.07$ \\
\hline \multicolumn{7}{|l|}{ BMI $\left(\mathrm{kg} / \mathrm{m}^{2}\right)$} \\
\hline Normal (18.5-24.9) & 1.00 & Ref. & 1.00 & Ref. & 1.00 & Ref. \\
\hline Underweight $(<18.5)$ & $2 \cdot 28^{\star \star}$ & $1.35,3.87$ & 1.34 & $0.75,2.40$ & $1.75^{\star \star}$ & $1.20,2.57$ \\
\hline Overweight $(\geq 25 \cdot 0)$ & $0.72^{\star \star \star}$ & $0.62,0.84$ & 0.88 & $0.74,1.05$ & $0.79^{\star \star \star}$ & $0.71,0.88$ \\
\hline \multicolumn{7}{|l|}{ Tobacco smoker } \\
\hline No & 1.00 & Ref. & 1.00 & Ref. & 1.00 & Ref. \\
\hline Yes & 0.12 & $0.73,3.37$ & 0.45 & $0 \cdot 18,1 \cdot 11$ & 0.85 & $0.48,1.50$ \\
\hline \multicolumn{7}{|l|}{ Waterpipe smoker } \\
\hline No & 1.00 & Ref. & 1.00 & Ref. & 1.00 & Ref. \\
\hline Yes & 0.71 & $0.39,1.27$ & 1.60 & $0.79,3.21$ & 1.03 & $0.66,1.60$ \\
\hline \multicolumn{7}{|l|}{ Cigarette smoker } \\
\hline No & 1.00 & Ref. & 1.00 & Ref. & 1.00 & Ref. \\
\hline Yes & 0.81 & $0.40,1.63$ & 1.26 & $0.55,2.87$ & 1.20 & $0.70,2.04$ \\
\hline
\end{tabular}

JPFHS, Jordan Population and Family Health Survey; Ref., reference category.

${ }^{\star} P<0.05,{ }^{\star *} P<0.01,{ }^{* \star *} P<0.001$.

†Adjusted OR include 6924 children with full information about all variables included in the multivariate model (in 2007, $n$ 3538; in 2009, $n$ 3386).

anaemia in urban areas, while the prevalence actually increased slightly in rural areas. The anaemia prevalence declined in children living in the central region of the country, but increased in those living in the northern and southern regions. In the central region, the public health problem of anaemia declined from severe to moderate; in the southern region, it increased from moderate to severe; and in the northern region, it remained moderate, although the prevalence increased. These geographical variations in the prevalence of anaemia can be linked to two factors: (i) most of the areas in the central region of the country are urban areas with low levels of poverty and illiteracy; and (ii) there is a possibility of variation in the distribution of fortified flour. A recent nationally representative survey in Jordan reported that only $44.1 \%$ of bread samples collected from households tested positive for the presence of $\mathrm{Fe}$, indicating that only some of the bread was fortified, and the percentage of adequately iodized salt samples was higher in urban areas than in rural areas ${ }^{(24)}$. The mill monitoring reports in Jordan for the sixteen months prior to 2010 found that of the thirteen mills that were supposed to produce fortified flour in Jordan, $84.6 \%$ did not fortify flour for five of the sixteen months, because they did not receive the premix ${ }^{(24)}$. This fluctuation in adding premix to the flour creates inequality in the access to the supplemented micronutrients across different regions in the country and also raises concern about increasing micronutrient deficiencies and prevalence of anaemia in the future. In Sweden, after 50 years of flour fortification with $\mathrm{Fe}$, withdrawal of the general Fe fortification resulted in a decrease of the total Fe intake by $39 \%$ and a substantial increase in the prevalence of $\mathrm{Fe}$ deficiency in girls ${ }^{(45)}$.

Blood $\mathrm{Hb}$ concentration is affected by tobacco smoke. Over the 2-year period, there was an observable decline in the prevalence of anaemia among children living with tobacco-smoking mothers. Passively and actively inhaled tobacco smoke increases the blood level of carboxyhaemoglobin, which is a type of $\mathrm{Hb}$ formed by the binding of carbon monoxide to $\mathrm{Hb}^{(46)}$. In smokers, the reduced oxyhaemoglobin levels due to the formation of carboxyhaemoglobin stimulate the production of erythropoietin, which increases the $\mathrm{Hb}$ concentration ${ }^{(47)}$. However, a positive relationship between low $\mathrm{Hb}$ concentration and passive exposure to tobacco smoke has been documented previously among infants ${ }^{(11,48)}$. In the present study we failed to document any positive relationship between passive exposure to mothers' tobacco smoke and childhood anaemia, even after stratifying the children according to the type of tobacco smoked by the mothers. This is in line with a previous report from Jordan which reported that while smoking by both parents was positively associated with anaemia in children, smoking by one of the parents was not associated 
with the development of anaemia in the children ${ }^{(11)}$. However, in the present study, only information about tobacco smoking by the mothers was available.

Breast-feeding for $\geq 6$ months was independently associated with an increased risk of childhood anaemia compared with breast-feeding for $<6$ months. Breastfeeding for $\geq 6$ months is associated with an increased risk of anaemia ${ }^{(46,49)}$. By 6 months, complementary foods are required to provide the $\mathrm{Fe}$ and other nutrients necessary for the development of the infant ${ }^{(49,50)}$. In Jordan it is a usual practice for mothers to introduce solid foods, including bread, to their babies by the fourth month of life. More than two-thirds of children under 6 months old in Jordan have already been introduced to complementary foods ${ }^{(27)}$. The WHO recommends exclusive breast-feeding for the first 6 months of life based on a review of different studies carried out prior to $2001^{(51)}$. However, because of the recent growing evidence of the association between exclusive breast-feeding and childhood anaemia, particularly in developing countries where anaemia is prevalent, there is a growing debate about whether solid foods should be introduced to babies before 6 months of age ${ }^{(52)}$.

In the current study we chose a cut-off of $\mathrm{Hb}<11.0 \mathrm{~g} / \mathrm{dl}$ to indicate anaemia because it is the WHO recommended and the most common cut-off point for pre-school children aged 6 months to 5 years ${ }^{(4)}$. However, use of different cut-offs such as $<12 \cdot 0 \mathrm{~g} / \mathrm{dl}$ used by the WHO for all children in the global burden of Fe-deficiency anaemia $^{(53)}$ or $10.5 \mathrm{~g} / \mathrm{dl}$ used by another study ${ }^{(54)}$ revealed a significant decline in anaemia prevalence among children tested in 2009 compared with those tested in 2007. Thus, anaemia trends over this study period declined significantly and should not have been affected by the different thresholds used.

The high prevalence of anaemia among children in Jordan compared with other countries in the region ${ }^{(2)}$ could be explained by different potential contributors, beyond factors revealed in our study. These factors include, but are not limited to: the decrease in consumption of white flour and fruits and vegetables from 2002 to 2008; in 2010 less than half of households were consuming fortified bread $^{(24)}$; economic crisis and increase in the cost of living, where the real growth in gross domestic product declined from $8.1 \%$ in 2005 to $2.6 \%$ in $2011^{(55)}$; in addition to the huge influx of refugees into the country who live under dire life circumstances and place extra burden on the available resources and food prices ${ }^{(56)}$. To achieve further decline in the prevalence of childhood anaemia in Jordan, more concerted efforts are needed. Anaemiarelated health education and a focus on parents (particularly mothers), rural areas and expansion of the fortification programme to other food items besides flour and salt, such as milk ${ }^{(51,57,58)}$ and rice ${ }^{(59)}$, are necessary. In high rice-consuming countries, such as Jordan, the WHO recommends rice fortification programmes for supplementing more essential minerals and vitamins to the general population ${ }^{(59)}$. Fortifying multiple food items should be preceded with assessment of intakes in the population, degree of small-scale and home production, and industry consolidation. As well, in food fortification, it is preferable to use food vehicles that are centrally processed $^{(60)}$. Fortifying centrally processed food has the potential to be an effective public health strategy for the elimination of micronutrient deficiencies and reducing the burden of anaemia. Promoting dietary diversity is another preferred strategy to improve the nutrition of a population $^{(60)}$. A comprehensive combination of these interventions would be expected to result in a rapid and significant further decline in the prevalence of childhood anaemia in Jordan.

The current findings should be interpreted bearing the following limitations in mind. First, the cross-sectional analysis limits establishment of a cause-and-effect relationship. Second, due to cultural barriers and beliefs, interviewing women in front of their family members may reduce the likelihood of obtaining correct answers about behavioural variables, such as smoking, and could result in response bias. In addition, due to the unavailability of information about the father's smoking status, we could not measure the association between exposure to both parents' smoking and the development of anaemia. Third, the decline in anaemia prevalence during the 2-year period could be also attributed to other changes independent of the fortification programme. For example, the difference in $\mathrm{Hb}$ level between the two survey phases could be subject to the seasonal vegetable and fruit supply in summer and winter, as well as by the seasonal difference in temperature. A large cross-sectional study reported significantly lower values of $\mathrm{Hb}$ in August ${ }^{(61)}$, which was attributed to increased plasma volume expansion ${ }^{(62-65)}$. Plasma volume during the summer was reported to be higher by $5.5 \%$ in healthy non-smokers ${ }^{(66)}$. One study found that seasonal change in $\mathrm{Hb}$ level was attributable to changes in the length of the day rather than changes in temperature ${ }^{(67)}$. On the other hand, the intake of vitamin $\mathrm{A}$, vitamin $\mathrm{B}_{6}$, folic acid, $\mathrm{Cu}$ and $\mathrm{Fe}$, which is considered to contribute to blood formation, is influenced by the availability of seasonal foods; the JPFHS-09 that showed higher $\mathrm{Hb}$ level was conducted in winter where more green leafy vegetables that contain vitamin $\mathrm{A}$, vitamin $\mathrm{B}_{6}$, folic acid, $\mathrm{Cu}$ and $\mathrm{Fe}$ are available compared with summer, which might influence the anaemia status. A study showed that the frequency of consumption of leafy vegetables that are rich in vitamins, $\mathrm{Cu}$ and $\mathrm{Fe}$ was higher during winter compared with summer, alongside higher mean $\mathrm{Hb}$ concentration during winter and the rainy season ${ }^{(68)}$. Fourth, the relative bioavailability and stability of micronutrients during processing, manufacturing, baking and storage were not assessed in the present study ${ }^{(60)}$. Finally, owing to the use of pre-existing data and defining anaemia based on the blood level of $\mathrm{Hb}$ alone, without testing for other indicators such as the serum ferritin, transferrin saturation 
and erythrocyte protoporphyrin levels, we could not identify the type of anaemia in individual subjects: whether it was related to nutritional, genetic, parasitic, or other physiological or infectious factors. However, the current findings are very important to fine-tune the development of national strategies to combat anaemia in Jordan.

\section{Conclusions}

The current study provides confirmatory evidence for the shift of the public health problem of anaemia in Jordanian children of pre-school age from severe to moderate. This decline has occurred following the initiation of a fortification programme of wheat flour and suggests the improvement in micronutrient deficiencies in these children as a result of nutritional strengthening of wheat flour with multiple micronutrients. However, anaemia in children still remains a public health issue affecting onethird of pre-school children in Jordan. Children aged $\leq 24$ months, children living in low socio-economic strata such as in rural areas, children living with anaemic mothers and children who are exclusively breast-fed for $\geq 6$ months are groups that are at increased risk for the development of anaemia.

\section{Acknowledgements}

Acknowledgements: The authors are greatly thankful to the Department of Statistics, Jordan and ICF Macro for the 2007 and 2009 JPFHS through the MEASURE DHS programme and to the individuals in Jordan who contributed to the 2007 and 2009 JPFHS. Financial support: This study was partly supported by a Grant-in-aid for Scientific Research from the Japan Society for the Promotion of Science (JSPS; grant number 24390164). The JPFHS-07 and JPFHS-09 were funded primarily by the Government of Jordan with additional funding from the US Agency for International Development (USAID) and the United Nations Population Fund (UNFPA). The funders had no role in the design, analysis or writing of this article. Conflict of interest: None. Authorship: R.A.R. and K.N. conceptualized and designed the study. R.A.R. obtained the data and R.A.R. and K.N. analysed the data. R.A.R. wrote the manuscript and K.N. and K.S. critically reviewed the manuscript. All authors approved the final manuscript. Ethics of buman subject participation: This study was conducted according to the principles laid down in the Declaration of Helsinki and all procedures involving human subjects were undertaken with the approval of the Ethics Review Committee for scientific researches in Jordan. Verbal informed consent was obtained from the children's mothers or caregivers prior to their participation in the study and the blood testing. Verbal consent was witnessed and formally recorded.

\section{References}

1. Kassebaum NJ, Jasrasaria R, Naghavi M et al. (2014) A systematic analysis of global anemia burden from 1990 to 2010. Blood 123, 615-624.

2. World Health Organization (2008) Worldwide Prevalence of Anaemia 1993-2005: WHO Global Database on Anaemia. Geneva: WHO.

3. World Health Organization (2005) WHO Global Database on Iron Deficiency and Anaemia, Micronutrient Deficiency Information System. Geneva: WHO.

4. World Health Organization (1989) Preventing and Controlling Iron Deficiency Anemia Through Primary Health Care. Geneva: WHO.

5. World Health Organization (2001) Iron Deficiency AnaemiaAssessment, Prevention, and Control: A Guide for Programme Managers. WHO/NHD/01.3. Geneva: WHO.

6. Kotecha PV (2011) Nutritional anemia in young children with focus on Asia and India. Indian J Community Med 36, 8-16.

7. Juyal R, Osmamy M, Black RE et al. (2004) Efficacy of micronutrient fortification of milk on morbidity in preschool children and growth - a double blind randomized controlled trial. Asia Pac J Clin Nutr 28, Suppl. 13, S44.

8. Siegel EH, Stoltzfus RJ, Khatry SK et al. (2006) epidemiology of anemia among 4- to 17-month-old children living in south central Nepal. Eur J Clin Nutr 60, 228-235.

9. World Health Organization \& Centers for Disease Control and Prevention (2007) Assessing the iron status of populations. http://www.who.int/nutrition/publications/micronutrients/ anaemia_iron_deficiency/9789241596107/en/_ (accessed February 2015).

10. Choi JW \& Kim SK (2005) Relationships of lead, copper, zinc, and cadmium levels versus hematopoiesis and iron parameters in healthy adolescents. Ann Clin Lab Sci 35, 428-434.

11. Hong R, Betancourt JA \& Ruiz-Beltran M (2007) Passive smoking as a risk factor of anemia in young children aged 0-35 months in Jordan. BMC Pediatr 7, 16.

12. Faber M, Swanevelder S \& Benade AJ (2005) Is there an association between the nutritional status of the mother and that of her 2-year-old to 5-year-old child? Int J Food Sci Nutr 56, 237-244.

13. Moench-Pfanner R, de Pee S, Bloem MW et al. (2005) Foodfor-work programs in Indonesia had a limited effect on anemia. J Nutr 135, 1423-1429.

14. Osório MM (2002) Determinant factors of anemia in children. J Pediatr (Rio J) 78, 269-278.

15. Demaeyer E \& Adiels-Tegman M (1985) The prevalence of anemia in the world. World Health Stat Q 38, 302-316.

16. World Health Organization (2013) Essential Nutrition Actions: Improving Maternal, Newborn, Infant and Young Child Health and Nutrition. Geneva: WHO.

17. Warrier RP, Dole MG, Warrier J et al. (1990) The anemia of malnutrition. In The Malnourished Child. Nestle Nutrition Workshop Series no. 19, pp. 71-72 [RM Suskind and L Lewinter-Suskind, editors]. New York: Nestlé/Raven Press.

18. Lynch SR (1997) Interaction of iron with other nutrients. Nutr Rev 55, 102-110.

19. Bloem MW (1995) Interdependence of vitamin A and iron: an important association for programmes of anemia control. Proc Nutr Soc 54, 501-508.

20. Horton S, Alderman H \& Rivera J (2009) Hunger and malnutrition. In Global Crises, Global Solutions, 2nd ed., pp. 305-333 [B Lomborg, editor]. Cambridge: Cambridge University Press.

21. Jai K Das, Rehana A, Salam, Rohail Kumar et al. (2013) Micronutrient fortification of food and its impact on woman and child health: a systematic review. Syst Rev 2, 67. 
22. Eichler K, Wieser S, Rüthemann I et al. (2012) Effects of micronutrient fortified milk and cereal food for infants and children: a systematic review. BMC Public Health 12, 506.

23. Gera T, Sachdev HS \& Boy E (2012) Effect of iron-fortified foods on hematologic and biological outcomes: systematic review of randomized controlled trials. Am J Clin Nutr $\mathbf{9 6}$, 309-324.

24. Global Alliance for Improved Nutrition (2011) National Micronutrient Survey: Jordan 2010. http://web1.sph.emory. edu/users/hpacho2/FolicAcidNutritionBulletinManuscript/ Jordan_2010.pdf (accessed March 2015).

25. Gibson RS (2005) Assessment of iron status. In Principles of Nutrition Assessment, 2nd ed., pp 443-450. Oxford: Oxford University Press.

26. Department of Statistics, Jordan \& Macro International Inc. (2008) Jordan Population and Family Health Survey 2007. Calverton, MD: Department of Statistics and Macro International Inc.

27. Department of Statistics, Jordan \& ICF Macro (2010) Jordan Population and Family Health Survey 2009. Calverton, MD: Department of Statistics and ICF Macro.

28. Centers for Disease Control and Prevention (1998) Recommendations to prevent and control iron deficiency in the United States. MMWR Recomm Rep 47, 1-29.

29. Dirren H, Logman MHGM, Barclay DV et al. (1994) Altitude correction for hemoglobin. Eur J Clin Nutr 48, 625-632.

30. Rutstein S \& Johnson K (2004) The DHS Wealth Index. DHS Comparative Reports no. 6. Calverton, MD: ORC Macro.

31. World Health Organization (2006) Child Growth Standards. http://www.who.int/childgrowth/standards/en/ (accessed February 2015).

32. Nordenberg D, Yip R \& Binkin NJ (1990) The effect of cigarette smoking on hemoglobin levels and anemia screening. JAMA 264, 1556-1559.

33. Centers for Disease Control and Prevention (1989) CDC criteria for anemia in children and childbearingaged women. MMWR Morb Mortal Wkly Rep 38, 400-404.

34. Britto JC, Cançado R \& Guerra-Shinohara EM (2014) Concentrations of blood folate in Brazilian studies prior to and after fortification of wheat and cornmeal (maizeflour) with folic acid: a review. Rev Bras Hematol Hemoter 36, 275-286.

35. Martorell R, Ascencio M, Tacsan L et al. (2015) Effectiveness evaluation of the food fortification program of Costa Rica: impact on anemia prevalence and hemoglobin concentrations in women and children. Am J Clin Nutr 101, 210-217.

36. Araújo CR, Uchimura TT, Fujimori E et al. (2013) Hemoglobin levels and prevalence of anemia in pregnant women assisted in primary health care services, before and after fortification of flour. Rev Bras Epidemiol 16, 535-545.

37. Fujimori E, Sato AP, Szarfarc SC et al. (2011) Anemia in Brazilian pregnant women before and after flour fortification with iron. Rev Saude Publica 45, 1027-1035.

38. Food Fortification Initiative (2015) Middle East. http://www. ffinetwork.org/regional_activity/middle_east.php (accessed May 2015).

39. Ewusie JE, Ahiadeke C, Beyene J et al. (2014) Prevalence of anemia among under-5 children in the Ghanaian population: estimates from the Ghana demographic and health survey. BMC Public Health 14, 626.

40. Assis AM, Santos LM, Martins MC et al. (1997) Distribution of anemia among preschool children from the semi-arid region of Bahia. Cad Saude Publica 13, 237-244.

41. Miglioli TC, Brito AM, Lira PI et al. (2010) Mother-child anemia in the State of Pernambuco, Brazil. Cad Saude Publica 26, 1807-1820.

42. Osório MM, Lira PIC \& Batista-Filho M (2001) Prevalence of anemia in children 6-59 months old in the state of Pernambuco, Brazil. Rev Panam Salud Publica 10, 101-107.

43. Stekel A (1984) Iron requirements in infancy and childhood. In Iron Nutrition in Infancy and Childbood.
Nestlé Nutrition Workshop Series no. 4, pp. 1-10 [A Stekel, editor]. New York: Nestlé/Raven Press.

44. Food and Agriculture Organization of the United Nations (1988) Requirements of Vitamin A, Iron, Folate and Vitamin $B_{12}$. Report of a Joint FAO/WHO Expert Consultation. FAO Food and Nutrition Series no. 23. Rome: FAO.

45. Sjöberg A \& Hulthén L (2015) Comparison of food habits, iron intake and iron status in adolescents before and after the withdrawal of the general iron fortification in Sweden. Eur J Clin Nutr 69, 494-500.

46. Maziak W, Ward KD, Afifi Soweid RA et al. (2004) Tobacco smoking using a waterpipe: a re-emerging strain in a global epidemic. Tob Control 13, 327-333.

47. Milman N \& Pedersen AN (2009) Blood haemoglobin concentrations are higher in smokers and heavy alcohol consumers than in non-smokers and abstainers: should we adjust the reference range? Ann Hematol 88, 687-694.

48. Gavalov SM, Soboleva MK, Deriagina LP et al. (1999) Effect of active and passive smoking on the course of pregnancy in women and on the establishment of the erythrocytic system in their children. Ter Arkh 63, 126-130.

49. Dewey KG, Cohen RJ, Rivera LL et al. (1998) Effects of age of introduction of complementary foods on iron status of breast-fed infants in Honduras. Am J Clin Nutr 67, 878-884.

50. Picciano MF (2001) Nutrient composition of human milk. Pediatr Clin North Am 48, 53-67.

51. World Health Organization (2001) Global Strategy for Infant and Young Child Feeding: The Optimal Duration of Exclusive Breastfeeding. Geneva: WHO.

52. Meinzen-Derr JK, Guerrero ML, Altaye M et al. (2006) Risk of infant anemia is associated with exclusive breast-feeding and maternal anemia in a Mexican cohort. $J$ Nutr 136, 452-458.

53. Rastogi T \& Mathers C (2002) Global Burden of Iron Deficiency Anaemia in the Year 2000. Geneva: WHO.

54. Domellöf M, Dewey KG, Lönnerdal B et al. (2002) The diagnostic criteria for iron deficiency anemia in infants should be reevaluated. $J$ Nutr 132, 3680-3686.

55. Global Finance (2015) Jordan GDP and Economic Data. https://www.gfmag.com/global-data/country-data/jordangdp-country-report (accessed May 2015).

56. United Nations High Commissioner for Refugees (2015) 2015 UNHCR country operations profile - Jordan. http://www. unhcr.org/pages/49e486566.html (accessed May 2015).

57. Daly A, MacDonald A, Aukett A et al. (1996) Prevention of anemia in inner city toddlers by an iron supplemented cows milk formula. Arch Dis Child 75, 9-16.

58. Torres MAA, Sato K \& Queiroz SS (1996) O leite em pó fortificado com ferro e vitamina C como medida de intervenção no combate a anemia carencial ferropriva em crianças atendidas em unidades básicas de saúde. Arch Latinoam Nutr 46, 113-117.

59. World Health Organization (2015) e-Library of Evidence for Nutrition Actions (eLENA). Fortification of rice. http://www. who.int/elena/titles/rice_fortification/en/ (accessed February 2015).

60. World Health Organization \& Food and Agricultural Organization of the United Nations (2006) Guidelines on food fortification with micronutrients. Edited by Lindsay Allen, Bruno de Benoist, Omar Dary and Richard Hurrell. http://www.who. int/nutrition/publications/guide_food_fortification_micronu trients.pdf (accessed May 2015).

61. Kristal-Boneh E, Froom P, Harari G et al. (1993) Seasonal changes in red blood cell parameters. Br J Haematol $\mathbf{8 5}$, 603-607.

62. Borgna-Pignatti C, Ventola M, Friedman D et al. (2006) Seasonal variation of pretransfusion hemoglobin levels in patients with thalassemia major. Blood 107, 355-357. 
63. Lau P, Hansen M \& Sererat M (1988) Influence of climate on donor referrals. Transfusion 28, 559-562.

64. Morimoto T, Shikaki K, Inoue T et al. (1969) Seasonal variation of water and electrolyte in serum with respect to homeostasis. Jpn J Phyisiol 19, 801-816.

65. Sawka MN, Convertino VA, Eichner ER et al. (2000) Blood volume: importance and adaptations to exercise training, environmental stresses, and trauma/sickness. Med Sci Sports Exerc 32, 332-348.
66. Kristal-Boneh E, Froom P, Harari G et al. (1997) Seasonal differences in blood cell parameters and the association with cigarette smoking. Clin Lab Haematol 19, 177-181.

67. Sjostrand T (1953) Volume and distribution of blood and their significance in regulating the circulation. Physiol Rev 33, 202-228.

68. Deepa KS, Bharati P \& Kasturiba B (2004) Seasonal variations in iron status of adolescent girls in Dharwad Taluk. J Hum Ecol 15, 175-178. 